and can be interpreted or used to govern an orchestration. But it is not an interactive or dynamic image.

John Avise from the University of California (D avis, CA, USA), reflects on the increasingly complex roles of transposable genetic elements in genomic evolution and regulation and has therefore advocated both the social and ecological pictures. Perhaps one can see the genome as a commune, he suggests-a tightly bound organization with an intricate division of labour (Avise, 2001). Or, harking back to an image first used by Lewis Thomas in the 1970s to depict the cell (Thomas, 1974), it might be helpful to liken the genome to an ecosystem in which different genes fill different niches.

Other possibilities draw on systems biology and focus on the properties of networks. A road network, for instance, is interconnected in ways that offer many different routes from $A$ to $B$. An individual gene might then be like a single road. Block it, and the traffic may still get through, although by a more circuitous path (M cFadden, 2005).

Probably the most striking image so far comes from M oss. He considers two stages of gene expression that are regulated by impressively large assemblies of molecules. First is transcription, in which the precise selection of exons for an RNA transcript depends on the presence or absence of a variety of transcription factors, which interact both with DNA and RNA polymerase. The second is post-transcriptional splicing, which is the task of the spliceosome, an intricate array of five small nuclear RNAs and as many as 150 separate proteins.

The scientific account of these operations has been built up by painstaking work over decades, and their sensitivity and exquisite modulation is still hard to grasp. Whole popular articles about the spliceosome, for instance, are now appearing that, although admirably clear in exposition, largely eschew memorable metaphors (Ast, 2005). Moss has one, though. The "decisions" about the final configuration of the mRNA are taken on the path from DNA to protein by "ad-hoc committees" (Moss, 2003). Think of each committee, he suggests, as a constituent assembly. The more members it has, the more information they can all draw on about the recent history of events in the cell, and its interactions with other cells. The committee is a way of pooling experience before a kind of consensus is reached about what to do next.
This is all very anthropomorphic, to be sure, but seems promising in several respects. These cellular assemblies create an image of a dynamic and flexible operation that is, like some human committees, wiser than any of the individual parts. It is only the beginning of what will be a long-running literary task, but the ad-hoc committee may win a niche as one of the metaphors of choice for conveying a new sense of how genes-and the cells in which they exist-work.

\section{REFEREN CES}

Ast G (2005) The alternative genome. Sci Am 292: 40-47

Avise J (2001) Evolving genomic metaphors: a new look at the language of D N A. Science 294: 86-87

Condit CM (1999) How the public understands genetics: non-deterministic and nondiscriminatory interpretations of the 'blueprint' metaphor. Public Understanding Sci 8: 169-180

Johannsen W (1911) The genotype conception of heredity. Am N at 45: 129-159

Keller EF (2000) The Century of the Gene. Cambridge, MA, USA: H arvard U niversity Press M cFadden J (2005) The unselfish gene. The Guardian 6 M ay, p22
M oss L (2003) What Genes Can't D o. Cambridge, MA, USA: MIT Press

Nerlich B, Hellsten I (2004) G enomics: shifts in metaphorical landscape between 2000 and 2003. N ew Genet Soc 23: 255-268

Rheinberger H-J (2000) G ene concepts: fragments from the perspective of molecular biology. In Beurton PJ, Falk R, Rheinberger H -J (eds) The Concept of the Gene in D evelopment and Evolution: $\mathrm{H}$ istorical and Epistemological Perspectives, pp 219-239. Cambridge, UK: Cambridge U niversity Press

Stotz K, G riffiths P (2004) Genes: philosophical analyses put to the test. Hist Philos Life Sci 26: $5-28$

Stotz K, G riffiths PE, Knight R (2004) H ow biologists conceptualize genes: an empirical study. Stud Hist Philos Biol Biomed Sci 35: 647-673

Stotz P, Bostanci A, G riffiths P (2005) Tracking the shift to 'postgenomics'. Community Genet, in the press

Thomas L (1974) The Lives of a Cell: N otes of a Biology Watcher. N ew York, NY, U SA: Viking Weigmann K (2004)The code, the text and the language of God. EMBO Rep 5: 116-118

\section{JonTumey}

doi:10.1038/sj.embor.7400521

\title{
The prize of discovery
}

\section{In identifying exciting research and individual excellence, prizes have an important, although often neglected, rolein science}

$T$ hese are the words every scientist would be happy to hear: "This is your cheque. And this is your diploma." Thus spoke Nobel laureate Rolf Zinkernagel, when handing over the 2005 Louis-Jeantet Prize for medicine to Alan Hall and Svante Pääbo at the Jeantet Foundation premises in Geneva, Switzerland, this A pril. Hall, Director of the Medical Research Council Laboratory for Molecular Cell Biology and the Cell Biology U nit at U niversity College, London $(U K)$, received the prize for his "pioneering work on the regulation of cytoskeleton dynamics in cell adhesion, migration and polarity". Pääbo, Director of the Max Planck Institute for Evolutionary Anthropology in Leipzig (Germany), was rewarded for "his innovative research on the evolution of the human genome in comparison to that of other primates".
Among all scientific prizes, the Nobel is king, topping others in nearly every aspect. It is the most prestigious, has the largest scientific committee, receives the most public attention, awards up to a million US dollars and is handed over by the King of Sweden. Nevertheless, scientific prizes come in all shapes and sizes, ranging in value from a token amount of money to a million euros or US dollars. Some are awarded during small ceremonies; others celebrate the winners in front of huge audiences. Many prizes are given for a specific discovery or contribution to a particular research field, whereas others are awarded for a scientist's life work or for contributions to society. Most prestigious prizes are international, but a large number of prizes award excellence on a national level. The Ig Nobel Prize, sponsored by the journal Annals of 
Improbable Research, is inflicted on scientists who have "done something that first makes people laugh, then makes them think", and is handed over by "genuinely bemused genuine Nobel laureates". Sometimes, a prize may not even go to a scientist, such as one of the 2000 Lasker Awards for Public Service, which went to the science section of The $\mathrm{New}$ York Times.

There is also no shortage of prizes to reward work in new and emerging research fields. In 2004, Finland established the Millennium Technology Prize; the first winner was Tim Berners-Lee, who received $€ 1$ million for inventing the worldwide web. And in early May 2005, the Norwegian Ministry of Education and Research announced the establishment of three prizes in partnership with the Kavli Foundation, led by Norwegian philanthropist Fred Kavli. The Kavli Prizes will award US\$1 million every two years for achievements in astrophysics, nanoscience and neuroscience. But it is not just big money that makes a prize important. Despite its modest value of CAD $\$ 15,000$, the Fields $M$ edal is the most prestigious award in mathematics and is commonly referred to as 'the Nobel Prize of mathematics'.

Most often, awards come as a complete surprise to their recipients. "My first thought was 'Is this a joke? Is this a hoax?' when [the Jeantet Foundation] called me," Hall recalled. He also admitted that he had not heard of the prize before he received it. In fact, with the exception of the N obel Prize and a few others, most scientists- not to mention the public-are not aware of the existence of scientific prizes. Regardless of whether they are big or small, reward a specific discovery or a life's work, scientific prizesand the committees that award themhave an important role in the scientific world. Not only do prizes mean a sudden and unsuspected infusion of cash for those who win them, but-more significantlythey identify both scientific excellence and important research topics and can thus help to overcome deeply entrenched dogmas in the scientific community. Sometimes, they also send an important signal to the public and politicians. This year's Paul Ehrlich and Ludwig Darmstädter Prize, awarded to Ian W ilmut from the Roslin Institute (Edinburgh, UK) for his cloning experiments, restarted the public debate on cloning and stem-cell research in Germany.

A prize jury regularly faces the difficult tasks of defining which research area to choose and selecting one or a few winners from a large pile of proposals. "Deciding on an area is not as difficult as defining the individuals," commented Paul Nurse, President of Rockefeller University (N ew York, NY, USA), member of the Lasker Awards jury and a winner of both the Lasker Award and the N obel Prize. "We have often quite

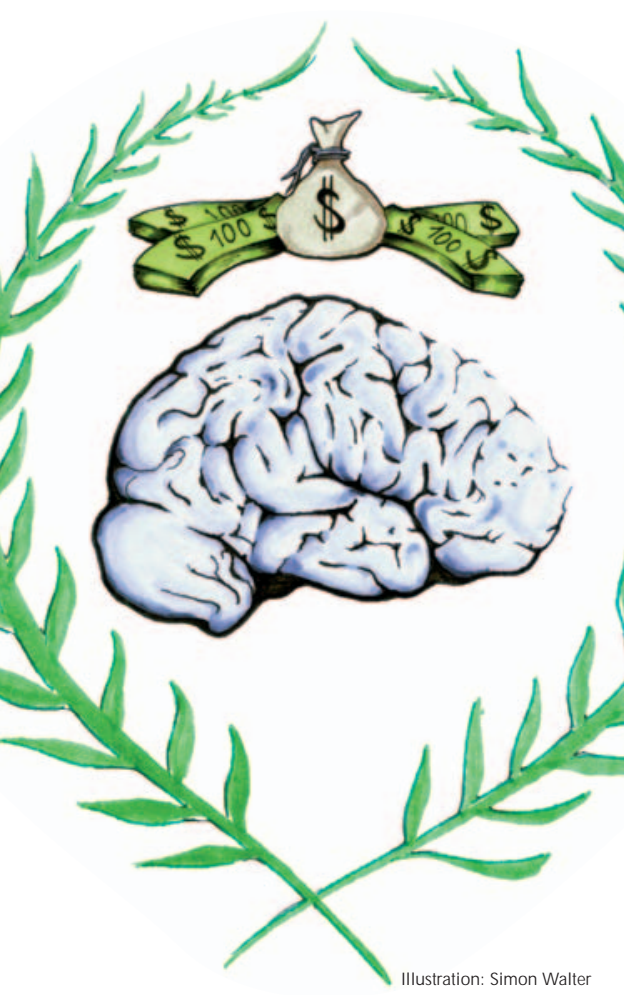

difficult discussions because of the quality of the people [proposed]." The Lasker Awards jury meet once a year for a full day to make final decisions about the winners, but reading and assessing every proposal that the Lasker Foundation receives over the course of a year precede this meeting. "It's a lengthy business," N urse said.

Jury members are usually guided by the founders' original intention when they select the research area and the prize winner, but quite often, the area is so broad that it leads to new discussions about what to reward. "The [Robert Koch] Prize is for any highly interesting

\section{... it is not just big money that makes a prizeimportant}

biomedicine," said Bernhard Fleckenstein, Director of the Institute for Clinical and Molecular Virology at the University of Erlangen-Nürnberg in Germany and member of the scientific committee of both the Koch and the Ehrlich Prizes. $\mathrm{He}$ said that when making their decision, Koch jury members sometimes engage in a basic discussion about "W hat would Robert Koch work on today?" Thus, although Koch was interested in infectious diseases, the prize can go to any biomedical research, such as this year's awards to Emil R. Unanue from Washington University School of Medicine (St Louis, MO, USA) for his work on antigen recognition, and Brian Druker from the Oregon Health \& Science University (Portland, OR, USA) for his work on tumour therapy. "[D ruker] has made a huge step forward" towards individual tumour therapies, Fleckenstein explained.

However, jury members are often free to stray from the original intention if they feel it is worthwhile to highlight a new research field. It is obvious why the 2005 Jeantet Prize for medicine went to Hall, as his work on cell migration and adhesion has direct implications for understanding the development of cancer and metastases; cancer killed French businessman Louis Jeantet in 1981. But it is less obvious why Pääbo's research was honoured. As jury member Richard Perham, Master of St John's College at the University of Cambridge, UK, explained: "This is the debate of the genome. The questions [Pääbo] is asking are about genetic individuality," and thus benefit the development of individualized medicine. "We're looking at landmark work here, not incremental discoveries." Derek Chadwick, also a jury member and Director of the Novartis Foundation (London, UK), sided with him, pointing out that Pääbo's prize is the sequel to Alec Jeffreys' 2004 award for the development of genomic fingerprinting: "[The prize] is for anything that asks what makes us human." 


\section{PRIZESAND THEIR FOUNDERS}

\section{- Warren Alpert Prize}

Warren Alpert, founder and chairman of Warren Equities, Inc., established his Foundation in Boston (M A, USA). Since 1986, the Foundation awards its Warren Alpert Prizeto "scientists and researchers from around the world ... for their contributions to humanity and their breakthroughs in the understanding and curing of major diseases".

\section{- Paul Ehrlich and Ludwig D armstädter Prize}

ThePaul Ehrlich Foundation in Frankfurt, Germany awards the Paul Ehrlich and Ludwig Darmstädter Prize annually. The prize is financed by German privateenterprises and the German government and is given for breakthrough research in biomedicine.

\section{- Fields Medal}

TheFields M edal is the mathematicians' equivalent of the Nobel Prize. Established in 1936 by John Charles Fields, a Canadian mathematician, it is given every four years to recognize breakthrough achievements by mathematicians not older than 40 years.

\section{- Gairdner Award}

The Gairdner Foundation in Toronto, Canada, is a non-profit corporation devoted to the recognition of outstanding achievements in biomedical research worldwide. Its annual Gairdner Award rewards"individuals whose work or contribution constitutes tangible achievement in the field of medical science".

\section{- Louis-Jeantet Prize}

Louis Jeantet, a wealthy French businessman, started theFondation Louis-Jeantet de M édecinein Geneva, Switzerland, to support cancer research. Since 1986, the Jeantet Foundation awards its Louis-Jeantet Prizefor medicine each year for important basic biomedical research.

\section{- Kavli Prize}

The Kavli Foundation (Santa Barbara, CA, USA) was created in 2000 by Fred Kavli, a N orwegian philanthropist who madehis fortunein the USA. Beginning in 2008, it will award the biennial Kavli Prizes at a ceremony in $\mathrm{O}$ slo, N orway, to recognize seminal advances in astrophysics, nanoscience and neuroscience.

\section{- Robert Koch Prize}

Since 1909, the Robert Koch Foundation in Bonn, Germany, awards the Robert Koch Prize for biomedical research each year. TheFoundation was started in 1907 to fight tuberculosis and was set up with private donations, among them 500,000 gold marks from US millionaireAndrew Carnegie.

\section{- The Lasker Award}

After the Second World War, US philanthropistsA Ibert and M ary Woodard Lasker founded the Albert and M ary Lasker Foundation in New York (NY, USA). The Lasker Award is given each year to recognize'stunning' achievements in basic and clinical research as well as significant public service on behalf of medical science.

\section{- Millennium Technology Prize}

The M illennium Technology Prize is the world'slargest technology prize to "celebrate inventions that have a favourableimpact on quality of lifeand well being. In particular, the prize seeks to highlight innovations that assist and enrich our everyday lives today as well as in the future." It is awarded by the Millennium PrizeFoundation, funded in part by private organizations and corporations, and in part by the Finnish government.

\section{- Nobel Prize}

The Nobel Prize, the most prestigious award in the life sciences, has been awarded annually since 1901 for breakthrough research in medicine, chemistry and physics, and for literature and peace. It was established by Alfred N obel, the inventor of dynamite. The Nobel Foundation in Stockholm, Sweden, selects the prizewinners.

\section{- John Scott Award}

The John Scott Award is given to "the most deserving men and women whose inventions have contributed in some outstanding way to the comfort, welfare and happiness of mankind" and is named after its donor, John Scott, an Edinburgh druggist. Thefirst awards weremade in 1834 for theinventions of the knitting machineand a door lock. $\mathrm{n}$ awarding research that may otherwise go unnoticed, prize juries also have an important role in sending a message to the scientific community about the importance of a particular research area. Stanley Prusiner's discovery that prions are the causal agent of scrapie, mad cow disease and Creutfeldt-Jakob disease was not widely accepted until he won the Lasker Award and the Nobel Prize for his work. Robin Warren and Barry Marshall's discovery that Helicobacter pylori cause gastritis and stomach ulcers was largely ignored by the medical community, who could not accept that a simple bacterium could be the cause of peptic ulcers. However, the fact that $\mathrm{M}$ arshall won a Lasker and a John Scott Award in 1995 and a Gairdner Foundation International Award in 1996, and shared the 1994 Warren Alpert Prize and the 1997 Ehrlich Prize with Warren, helped to make their discovery more acceptable. "It was a good idea and moderate methodology, but the perspective behind it is enormous," explained Fleckenstein. "Sometimes, you want to show a bit of courage." Jury members also showed courage in awarding the 2005 Ehrlich Prize, worth $€ 100,000$, to Ian Wilmut for his cloning experiments, a decision that was vehemently criticized in Germany by opponents of cloning and stem-cell research.

\section{... prizejuries have an important role in sending a message to the scientific community about the importance of a particular research area}

Unfortunately, the changing nature of biological research-towards bigger groups and larger scientific infrastructures-may make it harder to find the individual spark of genius. "Considering all the developments, the technical platforms, it becomes more and more difficult to identify individuals," said Bernard Rossier, secretary of the Jeantet Foundation's science committee. "But I think there is still a lot of room for individual and important discoveries. In biology, you can still trace back to the one or two most important papers." Nevertheless, $M$ arshall's discovery, made by swallowing a culture of Helicobacter and waiting for stomach ulcers to develop, is increasingly the exception. "That someone can do this 
in a garage, these days are long gone now," Perham said, adding that scientists also face increasing competition. "Anyone who has a good idea immediately faces competition from [other groups] with more postdocs and more money."

0 thers are more confident about being able to identify the one individual who made the pivotal contribution. "Individual excellence is actually quite easy to identify," Fleckenstein said, "if you take only originality as the sole criteria." He cited Kary Mullis' invention of the polymerase chain reaction as an example: "The publication was quite meagre; he would not be able to get a tenured position with this but it was enough for the Nobel Prize." Nurse also remains confident that juries will be able to find individual excellence, although it may take longer in some areas to establish a breakthrough discovery. "The prizes that reflect more molecular discoveries can take longer than the biological prizes," he said.

W hat is astonishing, though, is how obscure many scientific prizes remain, both to scientists and the general public. As Rossier pointed out, many winners of the Jeantet Prize do not know about the Foundation until they receive the award. This is quite different from the situation in the USA, where scientific prizes usually enjoy much more public attention. Nurse recalled that when he won the Lasker Award for basic medical research in 1998 while at the Imperial Cancer Research Fund in London, UK, it was widely covered by the US media but hardly reported in the UK. "There is definitely

\section{What is astonishing ... is how obscure many scientific prizes remain, both to scientists and the general public}

more interest in the USA in prizes than in Europe," he said. "First, science and scientists are really well respected in the USA ... and second, Americans like major achievements." Speaking of the situation in Germany, Fleckenstein also noted a lack of public and media interest-not even from dedicated scientific journalsin the Ehrlich and Koch Prizes, although both are highly prestigious awards internationally. "We live in different societies," Fleckenstein said. "We definitely would like to have a bit of the public acceptance of research that can be found in the USA."

This is a lost opportunity for society to highlight the importance of science and its achievements-an opportunity that the US media are more inclined to grasp. Given that science reporting in European mass media is rather scarce, prizes might be a way to attract public interest. "Prizes are good because they get science out into the mass media and into the public," Nurse said. "It gives you another coat hook to hang something on." To attract young students to a career in research, however, they may not be effective, $\mathrm{Hall}$ thinks. "Prizes are not necessarily good to attract young people to science," he said, as it is unlikely that someone would embark on a scientific career only to win the N obel Prize. In addition, the nature of a breakthrough discovery and the time it takes to develop such an insight means that scientific prizes predominantly go to more senior researchers. To support junior scientists at the postdoc level, Hall therefore favours young investigator awards or other funding possibilities to help them establish their first research group.

W hether or not it is used for research purposes, the money that comes with most prizes is no doubt a big help. Although many prizes, such as the Jeantet or the Koch, support the winners' laboratory, others, such as the Nobel, can be used in any way the laureate sees fit-2004 N obel laureate Paul Agre, for instance, announced that he would devote some of his prize money to political organizations bent on preventing the re-election of US President George W. Bush. Nurse, who bought a new motorcycle with his Nobel Prize money but also used it for research, thinks this is preferable. "Keeping it with the individual allows the individual to make certain decisions," he said. It may not necessarily make a difference to American scientists who are well paid, he pointed out, but it would be a huge help to an Eastern European scientist whose personal circumstances may not be as good.

In the end, however, it is scientific knowledge that is being celebrated and the individual's contribution to it. Whether a big or a small festivity, a token sum or a large amount of money, prizes are a welcome opportunity for scientists to get together in a relaxed and festive atmosphere and celebrate science.

\section{Hdger Breithaupt}

doi:10.1038/sj.embor.7400523 